\title{
POGLED NA SISTEM VASPITANJA I OBRAZOVANJA U NARODNOJ REPUBLICI KINI ${ }^{1}$
}

Apstrakt: O Kini se danas govori i piše, ipak, o sistemu vaspitanja i obrazovanja i o svakodnevici kineske škole malo znamo, a i to malo, često ne daje pravu sliku. Razmišljanje o kineskom bumu došlo je sa rezultatima PISA studije koja je 2009 godine u sam vrh postignuća postavila učenice i učenike Šangaja. Kojim kontekstualnim faktorima se mogu objasniti ovi izuzetni rezultati i kako oni deluju u svakodnevici kineske škole i nastave? U istorijskom kontekstu, radi se o uticajima konfucijanske tradicije koja visoko vrednuje učenje i respektuje učitelja. Ovome pripadaju i konsekvence političkog utemeljenja Narodne Republike Kine, kulturne revolucije, centralističkog upravljanja, kontrole sistema vaspitanja i obrazovanja koju sprovodi Komunistička partija.

U prilogu će se predstaviti struktura sistema vaspitanja i obrazovanja u NR Kini: od predškolskog, preko vaspitanja i obrazovanja u osnovnoj školi, nižoj i višoj srednjoj školi, do prijemnog ispita kao uslova za univerzitetsko obrazovanje. Prikazaće se obrazovanje i uloga nastavnika u kineskoj školi i društvu, didaktika i metodika nastave, kao i način na koji kineski učenici uče, strategija koju koriste i stava koji zauzimaju prema učenju i znanju.

Ključne reči: NR Kina, sistem vaspitanja i obrazovanja, nastavnik, didaktika

\section{POJAM OBRAZOVANJA U KINI}

Za razliku od srpskog jezika, koji zasebno definiše pojmove vaspitanja i obrazovanja, drugi jezici, npr. engleski, oba pojma sažimaju rečju „education“: Tako je i u kineskom jeziku, u kome postoji samo jedna reč za obrazovanje i vaspitanje: ,jiaoyu“".

Pod pojmom obrazovanje, ,podrazumeva se socijalna aktivnost koja je usko povezana sa ljudskim razvojem i društvenim napretkom. Oni koji posreduju obrazovanje, time istovremeno utiču na ideološki i moralni stav čoveka. U školskom kontekstu, obrazovanje znači posredovanje znanja i umeća kao i istovreme-

Pedagozi@ff.uns.ac.rs; Rad je nastao kao rezultat istraživanja u okviru Projekta Digitalne medijske tehnologije i društveno-obrazovne promene (Projekat br. 47020) koji se realizuje uz finansijsku podršku Ministarstva za nauku i tehnološki razvoj Republike Srbije za period 2011-2014. 
no uticanje tela i duha. Obrazovanje se često izjednačava sa ideološkim i moralnim vaspitanjem" (Chinese Encyclopedia 2009:132).

Pojam obrazovanja se ne može kratko i jasno definisati i generalno, bez obzira o kom govornom prostoru se radi, postoji konsensus o tome da je obrazovanje višeslojan, multidimenzionalan, dinamičan pojam na koji utiču istorija, društvo, kultura i politika zemlje. Obrazovanje i vaspitanje se uvek odigrava u socijalnom, kulturnom i društvenom kontekstu i zavisi od opštih političkih uslova, te se, stoga, obrazovni i vaspitni koncepti zapravo moraju orijentisati na temeljna društveno-politička uverenja i stavove i sa tim povezani ljudski i društveni pogled na svet. Ove odrednice snažno se reflektuju u sistemu vaspitanja i obrazovanja u Narodnoj Republici Kini. Kina se osvrće na istoriju dugu 5000 godina, u kojoj je pedagogija doživela mnogo preobražaja.

\section{IZGRADNJA I DANAŠNJA STRUKTURA OBRAZOVNOG SISTEMA}

Kineski školski sistem se deli na princip ,6+3+3+4“, što znači šest godina osnovne škole (xiaoxue), tri godine niže srednje škole (chuzhong), tri godinje više srednje škole (gaozhong) sa zaključnim trogodišnjim ili četvorogodišnjim školovanjem na viskokoj školi ili univerzitetu. Nakon maturiranja u nižoj srednjoj školi, učenici mogu da pohađaju stručnu poslovnu školu (zhongzhuan) ili tehničku stručnu školu (jixiao) (Edu 2001).

Naredna ilustracija prikazuje pregled sadašnjeg školskog sistema.

uzrast

\begin{tabular}{|c|c|}
\hline \multicolumn{2}{|c|}{ Doktorske studije (3 godine) } \\
\hline \multicolumn{2}{|c|}{ Master studije (2 godine) } \\
\hline $\begin{array}{l}\text { Univerzitet/Visoka } \\
\text { škola }\end{array}$ & Stručna škola \\
\hline Viša srednja škola & $\begin{array}{l}\text { Tehnička/zanatska } \\
\text { škola }\end{array}$ \\
\hline Niža srednja škola & \multirow[t]{2}{*}{ Obavezna škola } \\
\hline Osnovna škola & \\
\hline Predškolsko & \\
\hline
\end{tabular}

godina

$3-5$

Slika. 1: Izgradnja i struktura školskog sistema u NR Kini

\begin{tabular}{|l|}
\hline $\begin{array}{l}\text { Tercijarni } \\
\text { stepen }\end{array}$ \\
\hline $\begin{array}{l}\text { Sekundarni } \\
\text { stepen }\end{array}$ \\
\hline $\begin{array}{l}\text { Primarni } \\
\text { stepen }\end{array}$ \\
\hline $\begin{array}{l}\text { Predškolsko } \\
\text { obrazovanje }\end{array}$ \\
\hline
\end{tabular}

(Edu 2001) 


\section{Predškolski nivo}

U kineski predškolski sistem upisuju se deca u uzrastu od tri godine i gotovo sva deca u NR Kini danas pohađaju vrtiće. Širom države, 2011 god. ukupno 34,24 miliona dece registrovano u 166800 vrtića (Moe 2012a). Struktura vrtića varira $\mathrm{u}$ formi celodnevnog, poludnevnog i internatskog vrtića, ali je većina, ipak u formi celodnevnih vrtića tako da zaposleni roditelji imaju mogućnost da preko dana svoju decu ostave u dobrim rukama. Postoje i takozvani „,sezonski vrtići“ koji se brinu o deci samo za vreme radne sezone (Edu 2001a).

Za upis u vrtić deca moraju da polože prijemni ispit, tako da već u okviru vrtića postoje rangiranja. „Posebno dobri vrtići“ roditelje koštaju oko $20 \%$ porodičnog prihoda i najčešće imaju dugu listu za čekanje (Acuna 2011: 23). U vrtićima se deca razvrstavaju po uzrastu u grupu male dece (3-4 godine), grupe srednjeg uzrasta (4-5 godina) i predškolske grupe (5-6, odnosno 7 godina).

Zadatak vrtića definisan je kroz radno uređenje koje povezuje negu i vaspitanje dece sa ciljem telesnog, duhovnog, moralnog i estetskog vaspitanja. Obrazovnim sadržajima pripadaju, teme poput životnih i higijenskih navika, fizičko vaspitanje, moralno vaspitanje kao i osnovna znanja iz jezika i matematike, muzike i slikarstva (Wei\&Ye 2002:102). Posredovanje opštih znanja i prvih školskih osnova intenzivno treba da pripremi decu za sledeći korak u školovanju i da im probudi pozitivan stav prema učenju, tako da autori definišu tipičan kineski vrtić kao jednu osnovnu školu koja znači kraj detinjstvu i ulazak u stvarno kompetitivno društvo (Bond 1991: 11; 12)

\section{Osnovna škola}

Uvođenjem obaveznog pohađanja škole 1986 godine, osnovno obrazovanje je postiglo veliki napredak. Sva deca, sa navršenih šest godina, moraju da se upišu u osnovne škole, te je time u potpunosti postignut obrazovno-politički cilj devetogodišnjeg obaveznog pohađanja škole (99,79\%). Broj osnovnih škola poslednjih godina opada, 1998 god. zabeleženo je 609.626 osnovnih škola, a 2011 samo još 241.200 (Moe 2006; Edu 2001a; Moe 2012a).

Redukcija škola i sa tim povezano opadanje broja učenika krajem 70-ih je rezultat politike ,jedna porodica - jedno dete“. Primarna škola, sledi osnovni političko-ideološki nalog vaspitanja, naime (slično kao i u vrtićima) da se deca intelektualno, telesno i moralno vaspitaju. Redovno trajanje škole obuhvata period od šest godina. Deca obično šest godina pohađaju školu, a ako ne polože prijemni ispit, školovanje se može produžiti na sedam godina. Školska godina počinje 1. septembra, deli se na dva semestra u ukupnom trajanju 38 do 39 radnih, nastavnih nedelja, bez računanja raspusta od 13 nedelja koji je smešten između semestara. Nastava traje ceo dan sa četiri časa ujutru i tri časa popodne (Edu 2001a).

Nastavni plan obuhvata glavne predmete: kineski, matematiku, engleski i sporedne predmete poput prirodnih nauka, biologije, geografije, fizičkog, istorije, 
muzike, zanatstva i ideološke moralne nastave (Wei\&Ye 2002: 104; Acuna 2011: 25). Pošto roditelji kod kuće najčešće koriste dijalekt, deca tek u školi uče standardni mandarinski jezik, pa se na osnovu ovoga, u prvim godinama školovanja, posebna pažnja posvećuje kineskom, kao maternjem jeziku. Učenici pritom prvo uče fonetski pisani sistem „Pinyin“. Na kraju šeste godine školovanja, učenici moraju da polaže završni ispit kako bi bili primljeni u nižu srednju školu (Acuna 2011:25; Edu 2001a).

\section{Niža srednja škola}

Ispunjavanje devetogodišnjeg školovanja, povezano je sa pohađanjem sekundarnog stepena obrazovanja. Tu pored niže i više srednje škole pripadaju i sve stručne škole: srednje stručne škole, tehničke škole i zanatske škole (Acuna 2011: 26). 2011 godine je 50,66 miliona učenika pohađalo neku od ukupno 54100 nižih srednjih škola (Moe 2012a). Kvota za prelazak iz osnovne škole je iznosila 98,7\% (Moe 2010b). Na uzrastu od 12 godina, učenici se na osnovu položenog prijemnog ispita iz kineskog i matematike mogu upisivati u niže srednje škole. I u ovoj školi je školska godina (kao i u osnovnoj školi) podeljena na dva semestra, pri čemu školska godina obuhvata 39 do 40 radnih nedelja i 12 nedelja raspusta (Edu 2001a).

U nižoj srednjoj školi se predaju kineski, matematika, strani jezici, geografija, politika, biologija, fizika, hemija, istorija, fizičko, muzičko, likovno i nauke o radu (slično našem tehničkom obrazovanju). Pri tom su su u kurikulumu predviđenje i vannastavne aktivnosti. Opšti zadatak niže srednje škole jeste izgradnja „kvalifikovane radne snage i naučnih naraštaja“ (Acuna 2011: 27).

Na kraju niže srednje škole učenici moraju da polože završni ispit koji, ako se uspešno realizuje, važi istovremeno i kao potvrda za ispunjene devetogodišnje školske obaveze i za dozvolu polaganja prijemnog ispita za višu srednju školu. 2011 je kvota prelaznika iz niže u višu srednju školu iznosila 88,62 \% (Moe 2012a).

\section{Viša srednja škola}

Učenici, koji su završili nižu srednju školu, mogu kroz trogodišnje obrazovanje u višim srednjim školama da steknu pravo da polažu prijemni ispit (gao kao) za upis na univerzitet. Da bi upisali željeni fakultet, učenici moraju da polože regionalni prijemni ispit, kojim se proverava znanje iz predmeta: kineski jezik, matematika, strani jezik, fizika, hemija i politika. Ukoliko učenik ne položi ispit, on ima pravo da ga sledeće godine još jednom ponovi. Na osnovu podataka iz 2011. godine 24,55 miliona učenika je upisano na 13688 viših srednjih škola (Moe 2012a). Školska godina u višoj srednjoj školi ima od 40 do 42 nastavne nedelje, 10 do 11 nedelja raspusta i podeljena je na dva semestra (Edu 2001).

Na višim srednjim školama izučavaju se predmeti: kineski jezik, matematika, strani jezik, geografija, politika, fizika, biologija, hemija, istorija, sport, muzika, 
umetnost, nauka o radu, građansko vaspitanje, socijalni rad. Uz to su u kurikulumu predviđene i vannastavne aktivnosti, određeni izborni predmeti i kursevi (Wei\&Ye 2002: 105).

\section{Visoka škola}

Tercijarnom obrazovanju pripadaju univerziteti, visoke škole i visoke stručne škole. Za razliku od univerziteta, ostale institucije pružaju studentima više prakse. Budući studenti moraju najpre da polože nacionalni prijemni ispit, pri čemu je broj poena koji treba ostvariti za upis na višu stručnu školu manji nego broj poena koji je potreban za upis na univerzitet ili visoku školu (Acuna 2011:28).

Da bi se zadovoljila sve veća potražnja za naučno-stručnim kadrovima, visokoškolski sistem se od početka osamdesetih godina neprestano nadograđuje i reformiše. Posebno treba spomenuti „Projekt 211”, koji je sproveden na najboljim univerzitetima u zemlji sa ciljem da se organizuju tako da idu rame uz rame sa internacionalnim univerzitetima i da na taj način ubrzaju privredni napredak Kine. Rezultati visokoškolske reforme su bili visoki, pa se tako broj studenata u poslednjih 30 godina sa 250000 (1980) popeo na 23,01 miliona (2011). Broj visokih škola popeo se sa 675 (1980) na 2762 (2011) (Moe 2010a; Moe 2012a), ali uprkos ovom kvantitativnom rastu, društvene potrebe još uvek nisu dovoljno podmirene. Vlada je stoga, u svom aktuelnom dvanaestom petogodišnjem planu postavila cilj, da visoko školstvo i dalje usavršava, kako bi do kraja 2015. više od $20 \%$ stanovništva imalo završenu visoku školu.

Visoke škole imaju isti cilj kao i one u zapadnim industrijskim zemljama, da obrazuju najbolje stručnjake za razvoj u kulturi, nauci i tehnologiji. Visokoškolsko obrazovanje je podeljeno na studije stručnih visokih škola, koje traju od dve do tri godine, osnovne studije, za koje su predviđene četiri do pet godina, kao i dodatne master i doktorske studije, sa vremenom studiranja od dve do tri godine. Nakon osnovnih studija moguće je ostvariti titulu mastera, nakon koje postoji mogućnost da se stigne do titule doktora nauka (Wei\&Ye 2002:107; Chen 2003:123).

Studije na visokim školama su bile besplatne sve do osamdesetih godina. Nakon što je zakon o visokom školstvu stupio na snagu 1999. godine iznos koji se plaća na godišnjem nivou je između 3000 i 6000 juana (što je otprilike nekih 360 do 730 evra), pri čemu nastavni materijal, troškovi života itd. nisu uračunati. Studenti imaju pravo da podnesu zahtev za studentski kredit, koji bi trebali da vrate u roku od osam godina, a posebno nadareni studenti mogu dobiti stipendiju. Uprkos mogućnostima finansiranja i ponudama stipendija često čitave ušteđevine porodica odlaze na troškove studija njihove dece. Sa uvođenjem taksi za studiranje, studiranje na visokim školama je moguće nažalost još uvek samo za srednji sloj društva (Acuna 2011:29; Chen 2003:130; Shen, Wignjosaputro\&Stiller 2013). 


\section{Gao-Kao - Prijemni ispit za visoke škole}

Najvažniji prijemni ispit u životu svakog učenika je prijemni ispit za visoke škole (gao kao), koji je uveden 1977 god. i koji se sprovodi na nacionalnom nivou. Polaganjem ovog ispita osigurava se skoro jedini mogući pristup kineskim visokim školama, tako da jednom godišnje, početkom juna, u većim kineskim gradovima vlada apsolutno vanredno stanje.

„Ovih dana, gaokao je postao nešto poput prolećng festivala (...). On je veliki deo kineske kulture. Svake godine, tokom ta tri dana, saobraćaj se kontroliše na glavnim putevima, sve što može da skrene pažnju se obustavlja, i čitavo društvo se trudi da olakša život studentima, koji polažu test. To je pravi nacionalni događaj (...) ali za studente može biti veoma strašno, pa čak i traumatično iskustvo. Pod velikim si stresom, posebno ako dolaziš iz porodice, koja nema moćne veze ili dobru situiranost. I zato, ukoliko je to slučaj, tvoj čitav život može da zavisi od ta tri dana" (Yang 2012).

Postupak prijemnog ispita je kompleksan, težak i vremenski zahtevan. Kandidati moraju najpre da prođu kroz četvorostepeni postupak prijavljivanja kada se proveravaju formalnosti, obavlja politička procena, sistematski pregled i podnosi lična lista želja visokih škola. Tek nakon temeljnog pregleda ovih dokumenata, samo $20 \%$ učenika koji su završili višu srednju školu dobijaju mogućnost da pristupe prijemnom ispitu (Acuna 2011: 29 Ludwig 2009: 52).

Stvarni ispit je izgrađen po principu $3+x$. Kandidati moraju raditi pismeni ispit iz tri obavezna predmeta: kineski jezik i književnost, matematika i jedan strani jezik. U oblasti stranih jezika mogu birati između sedam stranih jezika (engleski, francuski, španski, italijanski, ruski, japanski i arapski), pri čemu se preferira engleski jezik. Ukoliko kandidat hoće da studira prirodne nauke, mora polagati dodatne predmete iz hemije i fizike. Kandidati za društvene nauke se dodatno ispituju u oblastima istorija i geografija. Oni, koji žele da studiraju neki strani jezik, neophodno je da polažu usmeni ispit iz tog stranog jezika. Za kandidata koji želi da studira prirodne nauke, ispitni maraton izgleda otprilike ovako: prvog dana pre podne polaže se ispit iz politike, popodne ispit iz fizike. Drugog dana ujutro organizuje se ispit iz matematike, a popodne ispit iz hemije. Trećeg, poslednjeg dana, kandidati moraju da rade pismene ispite iz kineskog jezika (pre podne) $i$ stranog jezika (popodne). Svi ispiti traju dva sata, ispit iz kineskog jezika dva i po sata. Tako da u okviru tri dana vreme određeno za ispite iznosi 12,5 sati (Acuna 2011: 30).

Ispiti se ocenjuju na osnovu sistema bodovanja, pri čemu se može maksimalno ostvariti 900 poena. Ukupni rezultat se dobija sabiranjem rezultata svih ispita, na osnovu ukupnog rezultata prave se rang liste i dele se mesta na fakultetima. Samo jedan od 1000 učesnika na ispitu osvoji rekord od 800 poena (Chen 2003:122). Onaj, koji položi završni ispit sa veoma visokim brojem poena (trenutno 700) može studirati na jednom od eltnih univerziteta u Kini i on poseduje nakon studija „kartu u prvoj klasi za poslovni svet". Trka oko prijema na univerzitete i visoke škole 
počinje obično još u osnovnoj školi. Ocene koje se ovde dobiju važe kao neka vrsta pasoša za pristup nekoj dobroj srednjoj školi, koja se opet posmatra kao odskočna daska za neku bolju visoku školu. Oni koji završe fakultet imaju bolja radna mesta i više izgleda za napredovanje.

Rang liste najboljih univerziteta objavljuju se na godišnjem nivou. Pored tih, postoje i takve rang liste, na kojima prva mesta zauzimaju one visoke škole, na kojima je studirala većina kineskih milionera. Na ovoj listi, koja je sačinjena od strane Chinese University Alumni Association, se 2010. našao i Pekinški univezitet sa svojih 63 najbogatija bivša studenta. Na aktuelnoj rang listi Pekinški univerzitet se nalazi na mestu broj dva (China Alumni-Network 2013).

Zbog strogoće, kojom teče postupak prijema, pritisak konkurencije raste među sve većim brojem kandidata. 9,15 miliona studenata učestvovalo je 2012. na gao kao ispitu, pri čemu je 72,3\% položilo ispit. Prijemni ispit za upis na visoku školu uživa veliki ugled u kineskom društvu i od velike je važnosti za učenike i njihove porodice. On značajno utiče na školski i privatan život. Iako se nalazi tek na kraju školovanja, uticaj gao kao se primećuje u osnovnoj školi, a delimično čak i u vrtiću.

Uspešno polaganje ispita određuje ne samo poslovnu i finansijsku budućnost učenika (i njegove porodice), nego povećava i socijalni prestiž u društvu. Kroz uvođenje sistema ispita, koji veoma podseća na mandarinsku tradiciju iz davnih vremena, pedagoški razvojni put postaje „pakao učenja i ispita” (Bond 1991: 28).

\section{PEDAGOGIJA}

Obrazovanje i nauka razvile su se u Narodnoj Republici Kini uz pomoć reformi i politike otvaranja, pri čemu, školsko obrazovanje u mnogome zavisi od ideoloških i političkih previranja, u kojima je pedagogija prvenstveno pratila politički cilj, sa osnovnom intencijom prenošenja principa koje je odredila Komunistička partije Kine. Naučne analize i rasprave u vezi obrazovanja i vaspitanja, procvetale su i razvile se, tek sa velikim privrednim rastom Kine, koji je u velikoj meri uticao i na pedagogiju. Reforme koje su sledile u pedagoškoj oblasti, dovele su do rekonstruisanja inicijalnog obrazovanja nastavnika, jer uprkos svim obrazovnopolitičkim inovacijama u glavama ljudi i dalje su se zadržali stari načini razmišljanja kao i stara pedagoška načela.

\section{Obrazovanje nastavnika}

Istorija obrazovanja nastavnika u Kini je veoma kratka. U Staroj Kini su obično penzionisani službenici ili oni, koji su pokušali da uče, ali nisu uspeli da polože ispit za službenike, bili nastavnici. Pri tome su postojale različite vrste nastavnika: seoski nastavnici, niži i viši nastavnici, kao i kućni učitelji, koje su ipak samo bogate porodice mogle da priušte. Posao nastavnika je u Staroj Kini bio isključivo posao muškaraca, a samom obrazovanju nastavnika nije se pridavao veliki značaj, te tada nije postojalo obrazovanje za nastavnički poziv u klasičnom smislu. Začetke 
modernizacije kineskog školskog sistema nalazimo u 19. veku, u tada rasprostranjenim misionarskim školama, a prva moderna pedagoška škola bila je osnovana 1897 godine u Šangaju. Tek početkom 20. veka izdat je ukaz, koji propisuje, da nastavnici moraju završiti četiri do pet godina neke pedagoške škole. Od tada se razvija i učvršćuje svest o neophodnosti bazičnog obrazovanja nastavnika, kako bi se razvio moderan školski sistem (Wohlfahrt 1992: 11; 23).

Kada je Komunistička partija Kine došla na vlast, ograničava se obrazovanje $i$ to prvenstveno na političko prevaspitavanje nastavnika. Prava politička ideologija računala se više nego stručna kvalifikacija, u skladu sa rečima „Biti crven i ujedno ekspert." Dolazilo je i vreme kampanja masovnog obrazovanja, u kojima je svako, ko malo više zna, mogao da predaje drugima. Ministar obrazovanja je 1951. utvrdio, da više od polovine svih ,kvalifikovanih” nastavnika poseduje samo završenu osnovnu školu (Wohlfahrt 1992:50). Cilj da se poboljša obrazovanje nastavnika nije bio ostvaren zbog mnogobrojnih političkih kampanja i revolucija i baš naprotiv, za vreme kulturne revolucije intelektualci i nastavnici bili su proterivani na sela, ponižavani i javno blamirani.

Kada se završila kulturna revolucija promenio se i položaj nastavnika, i sa novom partijskom ideologijom, težilo se i opsežnim reformama u školskom sistemu. Posao i poziv nastavnika trebalo je učiniti atraktivnijim kako kroz poboljšanje njihovog socijalnog statusa, tako i kroz dodatna finansijska sredstva. Donošenjem „Zakona o nastavnicima u NR Kini” 1993, u kom su opisana prava i obaveze nastavnika, i dalje se pratio cilj, da se društveni položaj nastavnika, koji su mnogo propatili tokom kulturne revolucije, poboljša. Tako je u članu 4 ovog zakona napisano:

„Vlada treba na više nivoa da usvoji mere, da ojača ideološko, političko i profesionalno obrazovanje nastavnika, da poboljša njihove uslove života kao i uslove na radu, da štiti njihova legitimna prava i interese, da poboljša njihov društveni status. Nastavnici treba da budu poštovani u čitavom društvu" (Moe 1994).

Pored visoke stručne kompetencije, nastavnici treba da poseduju ,ispravna” politička, ideološka i moralna načela, da bi učenicima (u skladu sa Komunističkom partijom Kine) mogli da služe kao moralni uzor:

„Nastavnici bi trebali da imaju sledeće obaveze:

(3) da prenose znanje učenicima o osnovnim prinicipima koji su definisani u ustavu, da ih edukuju patriotizmu, nacionalnom jedinstvu i pravnom sistemu, kao i da im pruže znanja o ideologiji, moralnosti, kulturi, nauci i tehnologiji, da organizuju i nadahnu učenike da se angažuju u dobrotvornim društvenim aktivnostima;

(4) da se brinu o svim učenicima, da ih vole, poštuju njihovo dostojanstvo i da usmeravaju njihovo napredovanje $u$ aspektima kao što su moralnost, inteligencija i fizički razvoj;

(6) da neprestano usavršavaju svoju ideološku političku svesnost i da poboljšaju svoje profesionalne kompetencije u obrazovanju i predavanju" (Moe 1994). 
Zakon o nastavnicima utvrđuje uz to, koju školu bi nastavnici trebalo da završe, tako da nastavnici, koji predaju u osnovnim školama, treba da imaju diplomu više pedagoške stručne škole. Nastavnici, koji predaju u nižim srednjim školama, bi trebali da završe visoku pedagošku stručnu školu. Oni koji završe visoku pedagošku školu ili neku drugu visoku školu (fakultet) smeju da predaju u višim srednjim školama (Edu 2001).

\begin{tabular}{|l|l|l|}
\hline Nastavnik & Profesionalno obrazovanje & Prethodno završena škola \\
\hline Osnovna škola & $\begin{array}{l}\text { Viša pedagoška stručna škola } \\
(3-4 \text { godine })\end{array}$ & Diploma niže srednje škole \\
\hline Niža srednja škola & $\begin{array}{l}\text { Pedagoška stručna škola } \\
(2-3 \text { godine })\end{array}$ & Diploma više srednje škole \\
\hline Viša srednja škola & $\begin{array}{l}\text { Visoka pedagoška škola/druga } \\
\text { visoka škola (fakultet) (4 godine) }\end{array}$ & $\begin{array}{l}\text { Diploma više srednje škole/ } \\
\text { Viša pedagoška stručna } \\
\text { škola }\end{array}$ \\
\hline
\end{tabular}

Tabela 1: Obrazovanje nastavnika (Moe 2012a)

Na osnovu novijih podataka, 99,72\% nastavnika osnovnih škola, 98,91\% nastavnika nižih srednjih škola i 95,73\% nastavnika viših srednjih škola imaju neophodno obrazovanje (Moe 2012a).

Struktura i sadržaj obrazovanja nastavnika variraju zavisno od obrazovne institucije. Pored uobičajenih predmeta na koje se stavlja težište kao na primer kineski jezik i književnost, matematika, strani jezik, istorija, biologija, geografija i prirodne nauke i njihove metodike nastave, budući nastavnici moraju polagati predmete poput psihologije, marksističko-lenjinističku teoriju i političko-ideološko vaspitanje. Između ostalog studenti moraju završiti i kurseve produktivnog rada, naučnog istraživanja, pedagoške prakse (šest nedelja) i neretko vojni trening (Edu 2001b).

Velika važnost se pridaje obrazovanju političke svesti. Studenti moraju ,zauzeti korektan politički stav, voleti svoju otadžbinu, verovati u socijalistički sistem, pobrinuti se za obrazovanje naroda, u ulozi nastavnika moraju da imaju otmeni način razmišljanja kao i da pokazuju uzorno ponašanje" (Li 2004: 97).

Nakon uspešnog završetka studija, studentima se dodeljuju svedočanstva da su sposobni da predaju, a na osnovu člana 10. zakona o nastavnicima. Sposobni za nastavničku službu su oni, „koji se pridržavaju ustava i zakona, koji se veoma interesuju za obrazovanje, imaju ispravan ideološki i moralan karakter, poseduju znanja o formalnom školstvu propisana u ovom zakonu ili su položili ispite za nacionalne nastavnike i imaju sposobnosti neophodne za obrazovanje i predavanje, 
koji nakon što su proglašeni za kvalifikovane, mogu dobiti kvalifikacije za nastavnike" (Moe 1994).

Na nekim državnim školama novi nastavnici moraju imati i probno vreme $u$ trajanju od godinu dana.

Uspeh nastavnika meri se time, koliko njegovih učenika uspe da se upiše na neku višu školu, kao i uspehom učenika na ispitima na kraju školske godine. Takođe, i za ovo se nalaze odrednice u kinenskom zakonu o obrazovanju nastavnika:

„Nastavnici koji su postigli odlične rezultate u obrazovanju i predavanju, treniranju kadra, naučnom istraživanju, obrazovnim reformama, razvoju škole, društvenoj službi i programima radi-uči, treba da budu pohvaljeni i nagrađeni od strane škola kojim pripadaju" (Moe 1994).

Trenutno se u Kini u okviru „Odredbe o produbljivanju reformi obrazovanja” obrazovanje nastavnika dalje reformiše. Cilj je, poboljšati kvalitet obrazovanja, tako što će se preraditi kurikulum, i time što će se zahtevati više obrazovanje nastavnika. U vezi sa tim nastavnici koji predaju u osnovnim školama i nižim srednjim školama, treba da se obrazuju na višim obrazovnim ustanovama, te bi stoga, pedagoške stručne škole, trebale postepeno da budu ukinute (Li 2004:101).

\section{Uloga nastavnika}

U kineskoj kulturi posao nastavnika važi (ponovo) kao jedan časan, dostojanstven posao. Još u Staroj Kini nastavnik je uživao najviši ugled u društvu, imao je autoritet i učenici su mu ukazivali poštovanje i bili poslušni prema njemu. Nastavnici su izgubili na ugledu posebno za vreme diktature Mao Cedunga paradoksalno, kada se pomisli na to, da je Mao 1919. i sam završio školu za nastavnika i nekoliko godina radio kao rektor u osnovnoj školi u Changsha (Wohlfahrt 1992: 33).

U modernoj Kini, takođe, deca se ponašaju prema nastavnicima kao prema strogom roditelju - pažljivo, mirno i sa puno poštovanja. Ponašanje nastavnika je jako važno, zato što on neprestano služi kao moralni uzor, učenici ne sumnjaju u njegov sud i nikada ga ne stavljaju u pitanje. Zato i ne čudi da se problemi zbog discipline u školskoj svakodnevici veoma retko pojavljuju. Ovakvo ponašanje je u društvenom hijerarhijskom mišljenju Kineza veoma zastupljeno (Bond 1991: 29).

Već u pisanom znaku za reč nastavnik (laoshi) prepoznaje se stara tradicija ponašanja punog poštovanja u odnosu prema nastavnicima. Ova reč je sačinjena od reči lao (star) i reči shi (majstor). Kada bismo je bukvalno preveli, ona znači „stari poštovani majstor”, pri čemu se sama reč „majstor“ u kineskom jeziku vezuje za visoko poštovanje. Godine 1987. vlada je utvrdila 10. septembar kao „Dan nastavnika" i na ovaj dan, veliča se rad nastavnika, tako što mu učenici uglavnom poklanjaju cveće, vaučere i druge znake pažnje. 


\section{Didaktika - metodika nastave}

Klasična nastava u Kini odvija se još uvek pretežno u formi frontalne nastave i sistema ispitivanja. Podseća u velikoj meri na metodiku nastave, koja je još u Staroj Kini bila veoma zastupljena, a tada je nastavnik čitao jednu knjigu za drugom, a zadatak učenika bio je da delove teksta ponove i nauče napamet (Wohlfahrt 1992:12) U kineskom jeziku je učenje neodvojivo povezano sa ponavljanjem. Reč „xue” znači „učiti, studirati”, ali i ,imitirati, oponašati.”

Nastavnici stoje i danas uglavnom čitav čas na jednom uzvišenom podestu ispred table i govore uz pomoć zvučnika zbog velikog broja učenika u razredu (koji ponekad može da dođe čak i do 70). Analiza interakcije nastavnici-učenici pokazuje, da kineski nastavnici u svojim odeljenjima dominiraju čak i do $90 \%$ vremena predviđenog za nastavu (Ni, Chiu\&Cheng 2010:146). Aktivnost učenika zasniva se pretežno na ponavljanju odeljaka iz tekstova i na odgovaranje na pitanja nastavnika. Bond zaključuje da: „Čak i danas postoji skoro magično uverenje u vrednost memorisanja" (Bond 1991: 27). Pitanja nastavnika su, pri tom, uglavnom tako usko formulisana, da se prilikom odgovaranja odnose samo na tačno-netačno ili na napamet naučene rečenice. Dalje interakcije su pored pažljivog slušanja, parafraziranje i prepisivanje. Učenici retko slobodno postavljaju pitanja, tj. tako, da ih ne inicira sam nastavnik. Često se javlja i strah, da će se prilikom odgovaranja na pitanja ,izgubiti ugled”, da će se pogrešni odgovori tako interpretirati, da se dođe do zaključka da učenik nije dovoljno učio. Neinicirana pitanja se veoma retko javljaju, zato što postoji strah, da se teškim pitanjima može dovesti u pitanje ugled i poštovanje nastavnika.

U školama ipak važi pravilo, da učenike ne treba dovoditi u situaciju zbog koje će „,izgubiti ugled“ i zbog koje će se pred celim razredom blamirati. Osećaj stida, koji se kod učenika javlja prilikom davanja pogrešnog odgovora, je po kineskoj tradiciji kazna samo po sebi. „Kineski studenti ostaju skromni prilikom uspeha i osećaju se krivim i stide se kada dođe do neuspeha, što je rezultat njihovog isticanja učenja kao dužnosti prema sebi samima (teže samoperfekciji) i dužnosti prema porodici i društvu" (Li 2004.)

U kineskoj nastavi stoje stoga u centru: učenje napamet, ponavljanje i prepisivanje. Pošto se kineski učenici nisu navikli, da aktivno učestvuju u nastavi, da slobodno kažu svoje mišljenje ili da postavljaju pitanja, kineski učenici su u poređenju sa učenicima sa Zapada nesamostalni, pasivni, konformistički i malo kreativni.

Uprkos svim kritikama o strukturama i metodama nastave, $u$ jednoj komparativnoj studiji kultura, utvrđeno je da je azijatska nastava (u Tajvanu i Japanu) znatno delotvornija nego nastava na zapadu (u Americi). Veći deo nastavnog vremena, korišćen je za naučne aktivnosti i za posredovanje nastavnih sadržaja. Pažnja učenika je veoma visoka, prelaženje sa jedne na drugu fazu nastave protiču veoma brzo i zauzimaju samo malo vremena. Azijska deca ređe 
se bave sporednim stvarima i stoga im je pažnja više usmerena na nastavu, mnogo manje vremena se troši na individualne delatnosti ili na grupni rad (Bond 1991:29).

U kineskoj nastavi su uglavnom zastupljeni novi mediji. Za osnovno opremanje učionica u gradskom području potrebni su projektori, kamere i ravni ekran. Upotrebom videa i powerpoint prezentacija monotoni nastavni sadržaji postaju zanimljiviji. Generalno gledajući ljudi u Kini su zatvoreni za inostrane metode učenja i podučavanja i to je testirano tek na nekim pilot projektima. Jedan bitan aspekt reforme kurikuluma iz 1992. odnosi se na podsticanje „raznovrsnosti materijala za učenje", s obzirom na novo koncipiranje školskih knjiga i pripremanje eksperimentalnih materijala za podučavanje. Implementacija vanškolske nastavne prakse, takođe je sadržana u nastavnim planovima. Ovim novim obrazovnim idejama trebao bi da se podstiče istraživački duh učenika kao i njihova kreativnost, takođe trebalo bi podržati kooperativno učenje, kao i povezivanje teorije (školskog učenja) i prakse sa ciljem, da se sposobnosti učenika podese potrebama društva. U nastavnoj praksi učenici bi trebali da se stimulišu živahnim i aktivnim učenjem i da tako dobiju sveukupno obrazovanje. Ipak, do sada uvedene mere, odnosile su se samo na smanjenje ukupnog obima nastave i njenog usmeravanja na određena težišta (na određene predmete). Uz to se implementacija odvijala samo u vannastavnim aktivnostima (Acuna 2011:25).

Do sada se ne nazire nikakav dugotrajniji trend, koji bi ukazao na to, da će konvencionalne i konzervativne metode učenja biti uskoro ukinute. Razlozi za to, nalaze se svakako u velikom broju učenika u učionicama, u ograničenim mestima u učionicama kao i u tradicionalnoj konfucijanskoj predstavi o prenošenju i prilagođavanju znanja, koja je duboko ukorenjena u glavama i učenika i nastavnika.

\section{Tako uče Kinezi - stav i ponašanje pri učenju}

Kineska kultura je poznata po tome, da se školi i učenju pridaje velika važnost. Ova kulturalna procena vrednosti ima svoje korene u prošlosti i do sada je zadržana u glavama ljudi. Mnogi istraživači su u prošlim decenijama otkrili, da faktori koji su vezani za kontekst kao i kulturalna ubeđenja igraju veliku ulogu kod učenja (Li 2004:126).

Obrazovanje je, u kineskom društvu u istorijsko-tradicionalnom smislu, igralo veoma veliku ulogu, i to pre svega, povezano sa mogućnošću, da se dođe do uzdizanja na društvenoj lestvici. Zato i ne čudi, da ne samo roditelji nego i deca, znanje i obrazovanje posmatraju kao fundamentalni zadatak i prioritetni životni cilj. Na osnovu šest studija, više od 20000 učenika iz Amerike, Japana i Kine (Beijing i Taiwan) je praćeno i proučavano od 1980. do 1992. godine tj. od vrtića do 11. razreda u svim oblicima škole. Autori Chen, Lee i Stevenson imali su cilj, da ovom višegodišnjm studijom, između ostalog, istraže ponašanje kineskih učenika prilikom učenja, njihove stavove kao i učešće roditelja, koji su takođe intervjuisani. U studiji se moglo zaključiti, da kineska deca (i njihovi roditelji) pridaju veliku važnost, sticanju dobrog obrazovanja, i navode, da to vide kao 
centralni životni cilj. Na pitanje „Kada bi vila trebala da ti ispuni neku želju, koja bi to želja bila?", $68 \%$ ispitane dece dalo je odgovor, koji je stajao u direktnoj vezi sa njihovim školskim obrazovanjem: „da idem na fakultet”, „da imam mnogo knjiga”, „da dobijem puno petica” itd. Takođe, $91 \%$ ispitanih majki imalo je želju da njihovo dete ide na visoku školu ili fakultet ili čak da završi postdiplomske studije (Chen, Lee\&Stevenson 1996:69; 84).

Kineski stav o učenju se umnogome razlikuje od stava prema učenju u zapadnim zemljama. U mnogim studijama je dokazano, da kineska deca mnogo više vremena provode u školi i u izradi domaćih zadataka, da je njihova pedagoška praksa efektivnija, da azijski roditelji imaju znatno viša očekivanja (u pogledu škole) od svoje dece i da su više uključeni u školski život svoje dece (Chen, Lee\&Stevenson, 1996; Li 2004:126). U skladu sa konfucijanskom tradicijom Kinezi veoma čvrsto veruju, da se školski uspeh zasniva na teškom radu i da manje počiva na imanentnim sposobnostima. Motivacija i volja, da se teško radi zarad boljeg školskog uspeha, potiče iz ubeđenja da društveni uspon ide zajedno sa školskim uspehom (Chen, Lee\&Stevenson 1996:86; Bond 1991: 30; Li 2004:126).

Kineski učenici obavljaju mnogo više domaćih zadataka nego njihovi američki konkurenti, i provode mnogo više vremena preko vikenda i raspusta učeći. Učenici prvog razreda iz Pekinga su proveli prosečno 65 minuta za odrađivanje dnevnih domaćih zadataka i na to potrošili više vremena nego na susret sa prijateljima (57 minuta) ili na gledanje televizije (45 minuta). Sličan rezultat je dobijen i kod učenika petog razreda, koji su 70 minuta potrošili na domaće zadatke, 54 minuta na druženje sa prijateljima i 48 minuta na gledanje televizije (Chen, Lee\&Stevenson 1996: 86).

S obzirom na kulturalna uverenja Chen, Lee \& Stevenson (1996) su došli do rezltata, da istorijske centralne vrednosti konfucijanizma i danas imaju veliki uticaj na odnos kineskih učenika prema učenju. Centar konfucijanskog verovanja je „samoperfekcija” ljudskog života kroz lično predavanje učenju. Ovo ubeđenje je usko povezano sa drugim konfucijanskim vrednostima kao npr. pietet (strahopoštovanje prema roditeljima) kao i poboljšanje društvenog statusa kroz obrazovanje (Li 2004:130).

Istraživanje metode učenja azijatskih učenika vodi do toga, da je učenje napamet korišćeno kao metoda, sa ciljem da se dođe do dubljeg razumevanja sadržaja koji se uče. Ponavljanje i učenje napamet veoma su tesno povezani sa procesom razumevanja. Autori su takođe zaključili da postoje velike razlike između kultura prilikom korišćenja strategija učenja. Dok britanski učenici koriste ponavljanje i učenje napamet da bi proverili da li se još mogu setiti sadržaja koje su učili, kineski učenici koriste tu metodu da bi stigli do dubljeg razumevanja znanja. Uz to, britanski učenici posmatraju proces shvatanja sadržaja koji se uče kao trenutni proces saznavanja, dok kineski učenici to posmatraju kao dugotrajan proces, koji se nadograđuje i koji zahteva ogroman umni napor, mnogo angažovanja i metodičkih postupaka (Li 2003; 2004). 
Li opisuje četvorostepeni model, po kom kineski učenici, na tipičan način uče:

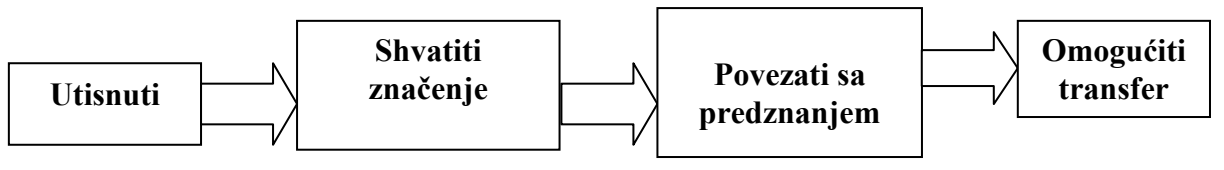

Slika 2: Četiri stepena učenja ( $L i$ 2004)

Kada se kineski učenici susretnu sa novim gradivom, počinju odmah da memorišu sadržaje u celini kroz učenje napamet i ponavljanje. U sledećem koraku pokušavaju da shvate smisao, svrhu, način i značaj sadržaja, koji su učili. Potom pokušavaju novonaučeno da povežu sa predznanjem i da ga primene u novim situacijama. U poslednjem koraku se naučeno, kroz verbalno ponavljanje i učenje napamet, dublje utiskuje i utiče na nove sadržaje koji se uče. Tako se odvija produbljujuće prodiranje gradiva (Li 2004:131).

Kineski učenici uče dakle, na jedan postepeni način, nadograđivanjem gradiva jedno na drugo. Tek kada se prethodni sadržaj razume i produbi, kreće se dalje na sledeći. U prvom planu stoji usvajanje novog znanja i u vezi sa tim učvršćivanje i dublje prodiranje kroz ponavljanje i učenje napamet. Ovaj postupak je veoma efektivan, jer kako soji u jednoj studiji 90\% studenata iz Hong Konga mogu da reprodukuju tekstove koje su učili u osnovnoj i srednjoj školi. Ovo mehanizovanje učenja se može objasniti već u osnovnoj školi time, da učenici i do 3000 kineskih znakova moraju da nauče napamet, što zahteva veliki rad i veliki napor (Kember\&Watkins 2010: 171).

$\mathrm{Na}$ ovaj način učenje ne ostaje površno, nego se, kroz komponentu učenja napamet dovodi do produbljenog razumevanja sadržaja. Autori, dalje, objašnjavaju uspeh kineskih učenika na testovima pre svega njihovim stavom prema učenju kao i strategijama učenja koje primenjuju, a koje su opet u vezi sa teškim radom i marljivošću. Istovremeno se naglašava, da i drugi faktori takođe, kao npr. kulturne predstave vrednosti kao i porodično i društveno okruženje, imaju veoma veliki uticaj (Chen, Lee \& Stevenson 1996: S.86).

\section{ZAVRŠNE KONSTATACIJE}

Učenici iz Šangaja su danas među najboljima na svetu. Šta čini ovaj obrazovni sistem tako uspešnim?

Mnogi faktori utiču na obrazovni sistem NR Kine. Kao prvo treba pomenuti kulturno-istorijske događaje, čije posledice još i danas znatno definišu vaspitanje i obrazovanje u Kini.

Raslojavanje zasnovano na obrazovnim postignućima se u većini slučajeva odvija već u zabavištu i provlači kao crvena nit kroz celokupno obrazovanje dece. Kao rezultat ,politike jednog deteta“ sva očekivanja su usmerena ka „malom caru“ ili „maloj carici“. Društveni pritisak na decu je ogroman. Lične neostvarene šanse 
za obrazovanje tokom kulturne revolucije su za stariju generaciju i dalje velika motivacija da obrazuju svoju decu koliko je ljudski moguće. Visok status, koji obrazovanje ima u Kini, ovo samo pojačava.

Cilj kineskih roditelja je: najbolje obrazovne mogućnosti za svoju decu i stoga očekuju najbolja postignuća i besprekorne ocene, jer samo tako će biti omogućen pristup na najbolje univerzitete, čiji završetak vodi ka najvišim pozicijama u privredi, upravi i politici. Školska nedelja đaka je, pre svega, definisana učenjem. Svaki dan su od 8 do 16 sati u školi, nakon čega slede domaći zadaci i učenje za kontrolne. Tokom vikenda i raspusta se često pohađaju dodatni kursevi, kako bi mogli da se takmiče sa ostalom decom. Učenici se posebno intenzivno pripremaju za ispite koji odlučuju o prelazu na sledeći nivo obrazovanja.

Kineski učenici ne samo da provode više vremena u učenju, nego i kvantitativno više uče. Po rezultatima PISA-istraživanja kineska deca pokazuju prednost u znanju koje pokazuje čak jednu školsku godinu više naspram drugih zemalja. Vlada pokušava da se bori protiv pritiska za postizanje postignuća i protiv preopterećenja dece. Kroz kurikularne promene obrazovni plan se ublažio. U 12. petogodišnjem planu izričito piše da obim domaćih zadataka treba da se smanji na maksimalno sat vremena dnevno, ali OECD kao i kineski obrazovni eksperti dolaze do zaključka „da ti napori još nisu urodili plodom“(Junker 2011). Sa jedne strane treba da se umanji pritisak, ali sistem, sa druge strane, to ne dozvoljava. Na kraju škole, učenike i dalje čeka prijemni ispit, „,crni jun“, kako ga učenici sa velikim poštovanjem nazivaju.

Obrazovni uspeh se, međutim, ne može svesti samo na pomenute tačke. Stav prema učenju ima svoje korenje duboko u konfucijanskoj prošlosti. Već tada se jedino kroz rad i trud moglo postati službenik. Kineski učenici imaju poseban stav prema učenju, a istraživanja pokazuju da kineska deca svoje akademske uspehe vide u trudu i mukotrpnom radu.

Pored stava prema učenju treba istaći i detinjastu pobožnost prema roditeljima. Kineska deca će učiti ne samo da bi kao odrasli dobili bolji posao, već i da bi svojim roditeljima i svojim porodicama ukazali čast. Kineski roditelji ulažu puno novca u obrazovanje dece, a loši rezultati ili čak neuspeh na prijemnom za fakultet značio bi ogromnu sramotu za porodicu.

PISA-istraživanje je pokazalo da u uspešnim obrazovnim sistemima nastavnici uživaju veliki društveni ugled. Učenici pokazuju nastavniku veliko poštovanje, oni mu se ne suprotstavljaju i ne postavljaju pitanja. Takođe PISA-istraživanje pokazuje da se u školama u kojima vlada veća disciplina, kao i bolji odnos između nastavnika i učenika, postižu bolji rezultati. Dobar nastavnik se u Kini meri po tome koliko izvanrednih učenika produkuje, a u zakonu o nastavnicima ovo je čak zapisano. Tako nastavnici koji postižu izvanredna postignuća dobijaju veće plate i dodatne alimentacije od države.

Procena učinka, koja se orijentiše prema rezultatima testiranja i selekcija učenika, postižu svoj vrhunac na prijemnom ispitu za univerzitet (gao kao). Stoga se prijemni na univerzitete u Kini upoređuje sa jednom scenom, gde „hiljadu 
vojnika sa deset hiljada konja pokušavaju da pređu uzani drveni most“. Univerzitetska diploma je u Kini postala preduslov da se dobije dobro plaćen posao.

Ovaj obrazovni sistem, orijentisan na postignuća, zahteva određen način učenja, koji se prvenstveno svodi na repetitivne kompetencije, ostavlja malo prostora za kreativno razmišljanje, kritičko posmatranje i problemsko učenje. Ovo stanje podržavaju etablirane društvene strukture, a u velikoj meri se inicira i kroz politiku. Pod kontrolom KP Kine su vaspitanje i obrazovanje postali industrijalizovani i standardizovani. Ni jedan učenik ne može da položi prijemni ispit, ako nije naučio standardizovane odgovore političke partije. KP Kine koristi učionicu za širenje svoje socijalističke ideologije. Ljubav prema državi je na prvom mestu; slobodno izražavanje misli i kritičko razmišljanje se u potpunosti potiskuju. Partija ne dozvoljava kritiku i proganja je čak i danas državnom represijom, te se obrazovni sistem i dalje drži pravolinijske strategije koja obezbeđuje takvo postojanje društva.

Kina svom silom teži ka svetskom vrhu. U područjima istraživanja i nauke ne želi više da računa samo na postojeće tehnologije, nego hoće da bude zemlja koja će obezbediti nova naučna saznanja i izume. Da li se ovakav cilj može postići pravolinijskim obrazovnim sistemom ili obrazovnim sistemom koji otvara prostor za kreativnost? U ovom poglede su kineski učenici još vrlo udaljeni od „savršenstva“, pogotovo od svetskog vrha, iako pobednici PISA-istraživanja zaslužuju veliko poštovanje.

\section{REVIEW OF EDUCATION SYSTEM IN PEOPLE'S REPUBLIC OF CHINA ${ }^{2}$}

\section{SUMMARY}

Abstract: Today, it is spoken and written about China, however, we know very few about education system and daily life of Chinese schools, and the few information we have do not provide us with real image. Thinking about Chinese boom came with PISA study results which set the students from Shanghai at the top of achievements. Which context factors can explain these exceptional results and how do they act in daily life of Chinese school and classes? In historical context, it is about the impacts of Confucian tradition that highly evaluates learning and respects the teacher. This includes also the consequences of political establishment of the People's Republic of China, cultural revolution, centralist management, education system control carried out by Communist party.

We will present the structure of education system in PR of China: from preschool, then education in elementary school, lower and higher level of secondary school, to entrance exam as a condition for university education. We will present the education and role of the teacher in Chinese school and society, didactics and methods of teaching in Chinese classrooms, as well as the manner in which Chinese pupils study, strategies they use and attitude they take towards learning and knowledge.

Key words: PR of China, Education system, teacher, didactics

The paper is a result of the research within the Project Digital media technologies and socially-educational changes (Project no. 47020), which is implemented with financial support of the Ministry of Science and Technological Development of the Republic of Serbia, for the period 2011-2014. 


\section{LITERATURA:}

Acuna, C. (2011) Bildung und Berufsbildung in der Volksrepublik China.Strukturen,Probleme und Perspektiven. Reihe China. Band 29. Hamburg: Diplomatica.

Bond, M.H. (1991) Beyond the Chinese Face. Insights from Psychology. Hong Kong. Oxford.

Chen, C., Lee, S. Y \& Stevenson, H. W. (1996) Academic achievements and motivation of chinese students. A cross-national perspective. U: Lau, S. (Ed.) Growing up the Chinese way. Chinese child and adolescent development. (pp.69-92). Hong Kong: The Chinese Uni Press.

Chen, H. (2003) Neuere Entwicklungen im chinesischen Hochschulwesen. U:Franke, R.F.\&mitter, W. (Hrsg.) Das Bildungswesen in China. Reform und Transformation. (s.121134). Köln. Böhlau.

China Alumni-Network (2013) Chinese university Ranking. [Online] Available: www.cuaa. net/2003/\#2013 [02.03.13].

Chinese Encyclopedia (2009) (2nd ed.) Beijing: Encyclopedia of China Publishing House.

Edu (China education and research network) (2001) Basic education in China. [Online] Available: http://www.edu.cn/introduction_1395/ [12.12.12]

Glöckner, C. (2013) Das Bildungswesen in China. U: Adick,C.(Hrsg.) Bildungsentwicklungen und Schulsysteme in Afrika, Asien, Lateinamerika und der Karibik. Historischvergleichende Sozialisations-und Bildungsforschung. Band 11. (s.191-212). Münster: Waxmann.

Junker, P. (2011) Pisa Erfolg. Chinas harte Schule. Der Tagesspiegel. [Online]. Verfügbar unter:http://www.tagesspiegel.de/wissen/pisa-erfolg-chinas-harte-schule/3699002. html8.12.12

Kember, D.\&Watkins, D. (2010) Approaches to learning and teaching by the Chinese. U: Bond, M.H. (Ed.) The Oxford handbook of Chinese Psychology. (pp.169-186). New York: Oxford.

Li, J. (2004) A Chinese cultural model of learning. U: Fan, L.,Wong, N.Y., Cai, J.\&Li, S. (Eds.) How Chinese learn mathematics. Perspectives from insider. (pp. 124-156). Singapore: World Scientific Publishing.

Ludwig, M. (2009) Schule und Mathematik im Reich der Mitte. U: Hafenbrak, B., Krebs, M., Ludwig, M. (Hrsg.) Frühstücksmathematik: 52 Beitr ge der Mathematik-Kolumne der Schw bischen Zeitung. (s. 51-53) 1. Auflage. Norderstedt: Books on Demand.

Moe (Ministry of Education) (1994) Teachers Law of the People's Republic of China. [Online] Available: http:www.moe.gov.cn/publicfiles/business/htmlfiles/

moe/ moe_2803/200907/49852.html [12.01.13].

Moe (Ministry of Education) (2006) Gesetz der Schulpflicht. [Online] Available: http:www. moe.edu.cn/publicfiles/business/htmlfiles/moe

moe_619/200606/15687.html [18.12.12].

Moe (Ministry of Education) (2010a) Anzahl der Schulen und Lehrkr fte. [Online] Available: http://www.moe.gov.cn/publicfiles/business/htmlfiles/moe/s6200/201201/129517.html [10.12.12].

Moe (2010b). (Ministry of Education) Abschlussquote der Schüler auf allen ebenen. [Online] Available: http://www.moe.edu.cn/publicfiles/business/htmlfiles/moe/ s6200/201201/129607.html [14.12.12].

Moe (Ministry of Education) (2012a) Bildungsstatistik 2011. [Online] Available: http://www. moe.edu.cn/publicfiles/business/htmlfiles/moe 
moe_633/201208/141305.html [14.12.12].

Ni, Y.J.,Chiu, M.M.\&Cheng, Z.J. (2010) Chinese children learning mathematics: From home to school. U: Bond, M.H. (Ed.) The Oxford handbook of Chinese Psychology. (pp.143-154). New York: Oxford.

Shen, X., Wignjosaputro, A. \& Stiller, F. (2013) Bildungslandschaft:China. Kooperation International. Eine Initiative vom Bundesministerium für Bildung und Forschung. [Online] Verfügbar unter: http:kooperation-international.de/buf/china/bildungsforschungslandschaft/ bildungslandschaft. html\#cl1939 [17.02.13]

$\mathrm{Su}$ (2007) China. Eine Eiführung in Geschichte, Kultur und Zivilisation. Krugzell: Chronic. Wang, X. (2002) Einleitung. U: Peez. H.\& Lukesch, H. (Hrsg.) Erziehung, Bildung und Sozialisation in der Volksrepublik China. (s. 13-19). Regensburg: Roderer.

Wei,X.\&Ye M.(2002) Die Schulische Erziehung.Schulische Erziehungs-und Unterrichtsziele. U: Peez, H.\& Lukesch, H. (Hrsg.) Erziehung, Bildung und Sozialisation in der Volksrepublik China. (s. 51-110). Regensburg: Roderer.

Wohlfahrt, A. (1992) Der Wandel des Lehrer-und Hochschullehrerbildes in der Volksrepublik China (Nr. 212) Hamburg: Institut für Asienkunde.

Yang, J. (2012) Are Your Kids smart enough for China's toughest test? Wall Street Journal. [Online] Available: http://blogs.wsj.com/speakeasy/2012/06/26/are-your-kids-smartenough- for-chinas-toughest-test/ [18.0.13] 